\title{
Deglaciation of the Northern Hemisphere at the onset of the Eemian and Holocene
}

\author{
Ralf Greve, ${ }^{1}$ Karl-Heinz Wyrwoll,${ }^{2}$ Anton Eisenhauer ${ }^{3}$ \\ ${ }^{1}$ Institut für Mechanik III, Technische Universität Darmstadt, Hochschulstraße 1, D-64289 Darmstadt, Germany \\ ${ }^{2}$ Department of Geography, The University of Western Australia, Nedlands, Perth, WA 6907, Australia \\ ${ }^{3}$ Geochemisches Institut, Universität Göttingen, Goldschmidtstraße 1, D-37077 Göttingen, Germany
}

\begin{abstract}
High resolution (TIMS) U-series dating of sea-level events obtained from coral-reef complexes suggests that global deglaciation from the Saale (penultimate) glacial to the Eem Interglacial (marine $\delta^{18} \mathrm{O}$ stages 6/5) may have occurred earlier in relation to Milankovitch insolation forcing than that from the Wisconsinan glacial to the Holocene Interglacial (marine $\delta^{18} \mathrm{O}$ stages 2/1). However, the interpretation of these data has been problematic because of the possibility of isotope exchange. In order to investigate whether these different lead-lag relations between Milankovitch forcing and ice volume are feasible from the point of view of large-scale ice-sheet dynamics and thermodynamics, the three-dimensional polythermal ice-sheet model SICOPOLIS (Simulation Code for Polythermal Ice Sheets) is applied to the entire Northern Hemisphere (which gives the major contribution to global ice-volume changes due to the relative stability of the Antarctic ice sheet) and simulations through the last two climatic cycles are conducted. The simulations cover the interval from $250 \mathrm{kyr}$ BP until today and are driven by surface-temperature reconstructions of deep ice cores (GRIP, Vostok) and simple parameterizations for the change of precipitation with time. Discussion of the results is focused on the Saale/Eem and the Wisconsinan/Holocene transitions. The amount and rate of deglaciation are in good agreement with the SPECMAP record for both cases, and the evidence of the data for an early start of the Eem Interglacial is supported.
\end{abstract}

\section{INTRODUGTION}

This paper addresses the question of whether there is a significant difference in the deglaciation histories during Termination II (marine $\delta^{18} \mathrm{O}$ stages 6/5, henceforth simply referred to as "stages") and Termination I (stages 2/1). Deglaciation and the associated ocean-volume changes of Termination I can be easily and accurately dated by standard radiometric techniques. With the development of thermal ionization mass spectrometric uranium series (TIMS U-series) dating (Edwards and others, 1987b), the prospect of establishing the timing of the Eem interglacial (substage 5e) events with errors of as little as $\pm 2-3 \mathrm{kyr}$ (at the $2 \sigma$ level) was encouraging. However, after a brief period of confidence in both the resolution and accuracy of this dating technique, it has become apparent that the reliability of TIMS U-series dating results is open to doubt because of problems of diagenesis and associated isotope-exchange processes commonly undergone by corals of Eem interglacial age (Hamelin and others, 1991; Henderson and others, 1993). Consequently, the suggestion that significant differences exist in the lead-lag relationships between Milankovitch insolation forcing and sea-level response between stages 6/5 and 2/1 (Chen and others, 1991; Zhu and others, 1993), can no longer be proposed with confidence. Therefore, we attempt to resolve the issue of a possible early sealevel high during substage $5 \mathrm{e}$ from a totally different and independent perspective, namely by placing it into the context of ice-sheet modelling. In this we use the SICOPOLIS (Simulation Code for Polythermal Ice Sheets) model
(Greve, 1995, 1997a) to establish whether the claim of differences in the ice response to insolation between Terminations I and II can be independently reproduced through dynamic-thermodynamic ice-sheet modelling.

\section{EEM INTERGLAGIAL SEA-LEVEL EVENTS - THE WIDER CONTEXT OF THE PROBLEM}

The possible existence of a high sea-level stand during the early part of the Eem Interglacial has been a long-standing issue (Bloom and others, 1974; Kaufman, 1986). The importance of this question lies in the fact that an early sea-level high at that time may question the traditional role ascribed to Milankovitch insolation variations as the direct driving force of glacial-interglacial transitions. More recently, results from a number of TIMS U-series-dated corals became available which suggested that during the Eem Interglacial, sea level was close to its present height by at least as early as 132000 years ago (Chen and others, 1991; Zhu and others, 1993; Szabo and others, 1994). However, problems of diagenesis and associated isotope exchange may invalidate some of the dates obtained (Henderson and others, 1993; Stirling and others, 1995). The discussion of an early sea level gains further support by the Devil's Hole isotope record (Winograd and others, 1992; Edwards and others, 1997), which also suggests an early onset of interglacial climate during substage $5 \mathrm{e}$.

The analytical procedures for $\mathrm{U}$ and $\mathrm{Th}$ separation, TIMS isotopic measurements and age calculations are now 
standard and well established (Edwards and others, 1987a; Chen and others, 1991). First, samples are screened for indications of recrystallization/exchange. A check on the validity of the dates obtained is given by a comparison of the calculated initial ${ }^{234} \mathrm{U} /{ }^{238} \mathrm{U}$ ratio of the samples dated with the known isotopic composition of sea water (for details of different requirements/interpretations see Chen and others, 1991; Zhu and others, 1993; Gallup and others, 1994; Szabo and others, 1994; Stirling and others, 1995). This check is a necessary prerequisite for the evaluation of dates, but it is not sufficient to demonstrate their accuracy. The problems have been brought into focus through the use of TIMS ${ }^{231} \mathrm{~Pa}$ dating of carbonates (Edwards and others, 1997). The application of this technique could provide an independent test on the claims of an early sea-level high during substage $5 \mathrm{e}$, by making it possible (in conjuction with Th dating) to obtain both primary and diagenetic ages, as well as constraints on the nature of the diagenetic processes (Edwards and others, 1997).

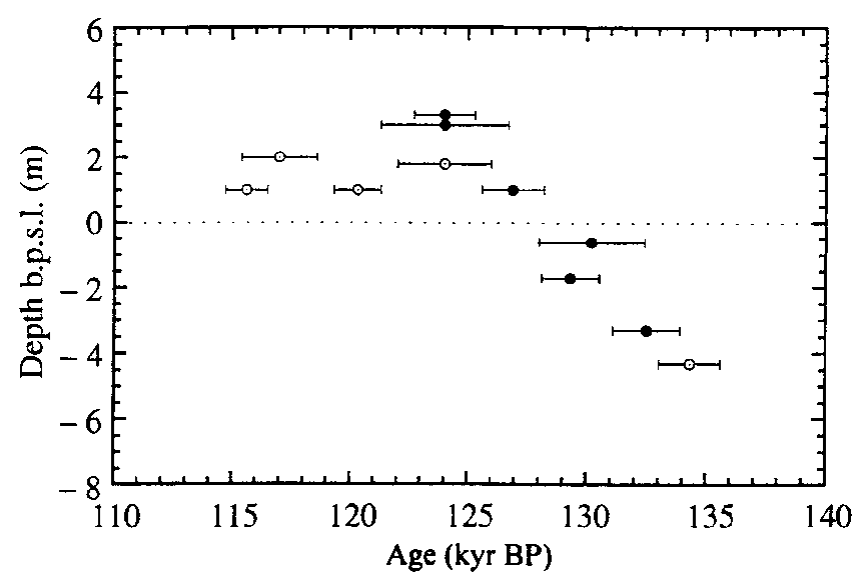

Fig. 1. Eem interglacial sea-level curve (U-series ages against depth below present sea level, b.p.s.l.) based on the Houtman Abrolhos U-series dates of Zhu and others (1993) (open circles) and Eisenhauer and others (1996) (full circles).

A general limitation of most Eem interglacial coral-reef studies is that the samples dated have been obtained from scattered outcrop. Usually what has been dated is the "peak" (and its persistence) of the Eem interglacial sea-level high. Consequently, the dates cannot be placed within a firm stratigraphic context, which would provide an additional check of their validity. In our work, we have obtained stratigraphically secured TIMS U-series dates (for the details see Eisenhauer and others, 1996) which not only allow us to date the sea level "peak", but also the events leading up to it. The dates come from the upper part of a core obtained from the Houtman Abrolhos reef complex, which is a series of shelf-edge coral reefs located some $70 \mathrm{~km}$ off the coast of the central western margin of Australia. The samples which were dated were screened for diagenetic changes using methods and selection criteria developed in an earlier stage of the project (Zhu and others, 1993). Because of their stratigraphic context, we have sufficient confidence in the results to consider it worthwhile exploring whether our claims could be independently tested through ice-sheet modelling.

The sea-level scenario which results from the TIMS Useries dates (Fig. 1) shows a sea level close to its present height by about $130 \mathrm{kyr}$ BP (calendar years before present), much earlier than the commonly claimed date of 124 kyr BP. If these results are valid, they imply that the insolation-sealevel lead-lag relationship of stages 6 to 5 (Termination II) was fundamentally different from that associated with the glacial-interglacial switch of stages 2 to 1 (Termination I). During Termination I, insolation levels at $65^{\circ} \mathrm{N}$ (traditionally taken to be the "forcing" latitude) peaked as early as 11000 years ago, while sea levels at the western margin of Australia did not peak until about 6500 years ago (Eisenhauer and others, 1993; Wyrwoll and others, 1995). If, during Termination II, sea level in the western Australian region was already close to its present height by about 130000 years ago, this would have occurred some 2000 years before the occurrence of the $65^{\circ} \mathrm{N}$ insolation maximum. If correct, such a conclusion would open the question as to how Milankovitch insolation and ice-volume interactions might have differed between Termination I and II, as well as having implications for the veracity of the SPECMAP chronology (Imbrie and others, 1984).

\section{ICE-SHEET MODEL SICOPOLIS}

SICOPOLIS is a three-dimensional dynamic-thermodynamic ice-sheet model based on the continuum-mechanical theory of polythermal ice masses (Fowler and Larson, 1978; Hutter, 1982, 1993; Calov and Hutter, 1997; Greve, 1997b). It simulates the time-dependent extent, thickness, velocity, temperature, water content and age for grounded ice sheets in response to external forcing. Further, possible basal layers of temperate ice (at the pressure-melting point) can be monitored computationally with high vertical resolution by fulfilling the Stefan-type conditions at the coldtemperate transition surface (this procedure is referred to as the "polythermal mode", where the term polythermal means the simultaneous existence of cold and temperate ice within an ice body). External forcing is specified by (1) mean annual air temperature above the ice; (2) surface mass balance (accumulation, surface melting); (3) sea level surrounding the ice sheet; and (4) geothermal heat flux from below. The particular dynamics of possible adjacent ice shelves is not accounted for. The model is discussed in greater detail by Greve (1995, 1997a).

Because of the extremely large RAM space and CPU time requirements of the polythermal mode when applied to a model domain as large as the entire Northern Hemisphere with reasonably fine horizontal resolution ( $\leq 100 \mathrm{~km}$ ), we switched it off ("cold-ice mode": the Stefantype conditions at the cold-temperate transition surface are ignored, computed temperatures above pressure melting are artificially reset to pressure melting instead) in the simulations conducted for this study. Greve (1997a) demonstrates that application of the cold-ice mode, instead of the polythermal mode, has only a relatively small effect on the large-scale properties of the simulated ice sheet and also on the basal area of temperate ice. The volume and thickness of overlying layers of temperate ice cannot be predicted accurately in the cold-ice mode. This loss of fine-structure information is accepted here.

In this study, SICOPOLIS is applied to the entire Northern Hemisphere prone to extended glaciation, projected to a polar stereographic map with standard parallel at $71^{\circ} \mathrm{N}$. The results of transient palaeoclimatic simulations which cover two entire glacial-interglacial cycles are discussed, focusing 
on the deglaciation and associated sea-level rise at the onset of the Eemian and of the Holocene. Horizontal grid spacing is $80 \mathrm{~km}$, which corresponds to $157 \times 157$ gridpoints in the stereographic plane. The distortions due to the projection from the hemisphere to the plane are accounted for in the computations. The vertical resolution is 21 gridpoints in the ice region and 11 gridpoints in the lithosphere.

\section{PARAMETERIZATION OF THE NORTHERN HEMISPHERE GLIMATE}

The model SICOPOLIS requires the mean annual air temperature above the ice, $T_{\text {ma }}$, the snow accumulation, $S$, and the surface melting, $M$, as space- and time-dependent boundary conditions. These quantities are fairly well determined for the present; however, for past climate conditions some simplifying assumptions must be made, as only sparse information is at hand.

\subsection{Present conditions}

The present topography of the bedrock is constructed based on the ETOPO5 (1988) land and sea-floor elevations, which are gridded with a resolution of $5^{\prime}$ in latitude and longitude. In the area of the present Greenland ice sheet, where this dataset gives the ice surface instead of the bedrock, the bedrock data of Letréguilly and others (1991) with $20 \mathrm{~km}$ resolution in the stereographic plane are applied.

For the present distribution of the surface air temperature, ECMWF (European Centre for Medium-range Weather Forecasts) data of the years 1986-89 and 1991-94 are used. These data are available as monthly means for midnight and midday and are averaged to seasonal means: $T_{\text {mam }}$ (spring: March, April, May); $T_{\mathrm{jja}}$ (summer: June, July, August); $T_{\text {son }}$ (autumn: September, October, November); and $T_{\mathrm{djf}}$ (winter: December, January, February).

Similarly, the present precipitation is based on mean monthly precipitation data by Jaeger (1976), from which the seasonal means $P_{\text {mam }}, P_{\mathrm{jja}}, P_{\text {son }}$ and $P_{\mathrm{djf}}$ are computed. As only solid precipitation contributes to the formation of ice sheets, these mean seasonal precipitations are transformed to mean seasonal snowfall rates, $S$, by the empirical relation (Marsiat, 1994)

$$
S_{\text {mam }}=P_{\text {mam }} \times \begin{cases}0, & T_{\operatorname{mam}} \geq 7^{\circ} \mathrm{C}, \\ \left(7^{\circ} \mathrm{C}-T_{\operatorname{mam}}\right) / 17^{\circ} \mathrm{C}, & -10^{\circ} \mathrm{C} \leq T_{\operatorname{mam}} \leq 7^{\circ} \mathrm{C}, \\ 1, & T_{\operatorname{mam}} \leq-10^{\circ} \mathrm{C},\end{cases}
$$

and accordingly for $S_{\mathrm{jja}}, S_{\mathrm{son}}, S_{\mathrm{djf}}$.

Surface melting, $M$, is parameterized by the degree-day method (Braithwaite and Olesen, 1989; Reeh, 1991), with different degree-day factors for the melting of snow, $\beta_{\text {snow }}$, and for the melting of ice, $\beta_{\text {ice. }}$ The air temperature is hereby assumed to follow a sinusoidal annual cycle with amplitude $T_{\mathrm{jja}}-T_{\mathrm{ma}}$, and additional variations due to the diurnal cycle and changing weather conditions are treated as normally distributed statistical variations with standard deviation $\sigma_{\text {stat }}$. Instead of the conventional purely numerical evaluation of the integrals for the resulting positive degree days (Reeh, 1991; Huybrechts, 1993), Calov's (personal communication, 1997) semi-analytical solution is employed, which is more precise and saves a considerable amount of CPU time.

\subsection{Past conditions}

The surface air temperature of the Northern Hemisphere at any time in the past can differ from the present one for two reasons: (a) the climate is generally colder or warmer, and (b) the surface elevation has changed. The former is described by a purely time-dependent offset $\Delta T_{\text {air }}(t)$, the latter by a lapse rate $\gamma_{t}$ :

$$
T_{\text {mam }}=T_{\text {mam }}^{\text {present }} \exp \left(\gamma_{\mathrm{t}}\left(h-h_{\mathrm{ref}}\right)\right)+\Delta T_{\mathrm{air}}(t)
$$

correspondingly for $T_{\mathrm{jja}}, T_{\mathrm{son}}, T_{\mathrm{djf}}$. Hereby, $h_{\text {ref }}$ is the reference elevation for the present temperature and precipitation data, which correspond to the present land and sea surface, respectively.

The past precipitation at the reference elevation $h_{\text {ref }}$ is assumed to be linearly coupled to the air-temperature deviation $\Delta T_{\text {air }}$ :

$$
P\left(h_{\text {ref }}\right)=P_{\text {present }}\left(1+\gamma_{\mathrm{s}} \Delta T_{\text {air }}(t)\right) .
$$

Further, elevation desertification due to the decreasing amount of water vapour in the air is accounted for by prescribing a $50 \%$ precipitation reduction per $\mathrm{km}$ elevation above $h_{0}=2 \mathrm{~km}$ (Budd and Smith, 1981):

$$
P=P\left(h_{\text {ref }}\right) \times \begin{cases}\exp \left(\gamma_{\mathrm{p}}\left[\max \left(h, h_{0}\right)-h_{0}\right]\right), & h_{\text {ref }} \leq h_{0}, \\ \exp \left(\gamma_{\mathrm{p}}\left[\max \left(h, h_{0}\right)-h_{\mathrm{ref}}\right]\right), & h_{\text {ref }} \geq h_{0},\end{cases}
$$

with $\gamma_{\mathrm{p}}=-0.6931 \mathrm{~km}^{-1}$. Again, Equations (3) and (4) are evaluated separately for the four seasons, and conversion to the seasonal accumulations, $S$, is done by Equation (1). Also, the parameterization of surface melting is the same as for present conditions.

\section{SIMULATION SET-UP}

Two simulations of transient Northern Hemisphere glaciation which cover the last two climate cycles have been set up:

\section{Simulation nt012:}

Model time: from $t=-250 \mathrm{kyr}(250 \mathrm{kyr} \mathrm{BP})$ until $t=0$ (today).

Degree-day model: $\beta_{\text {snow }}=3 \mathrm{~mm}$ w.e. $\times\left(\mathrm{d}^{\circ} \mathrm{C}\right)^{-1}, \beta_{\text {ice }}=$ $12 \mathrm{~mm}$ w.e. $\times\left(\mathrm{d}^{\circ} \mathrm{C}\right)^{-1}$ (w.e.: water equivalent), $\sigma_{\text {stat }}=5^{\circ} \mathrm{C}$ Geothermal heat flux: $Q_{\text {geoth }}^{\perp}=55 \mathrm{~mW} \mathrm{~m}^{-2}$.

Isostatic bedrock adjustment: local-lithosphere relaxingasthenosphere model (Le Meur and Huybrechts, 1996) with asthenospheric time-lag $\tau_{\mathrm{V}}=3000 \mathrm{yr}$.

Air-temperature forcing: reconstruction derived from the $\delta^{18} \mathrm{O}$ profile of the central Greenland GRIP (Greenland Icecore Project) core (Dansgaard and others, 1993) and the conversion formula (Johnsen and others, 1995)

$$
T_{\mathrm{ma}}^{\mathrm{GRIP}}(t)=\alpha+\beta \delta^{18} \mathrm{O}(t)+\gamma\left(\delta^{18} \mathrm{O}\right)^{2}(t),
$$

where $T_{\text {ma }}^{\text {GRIP }}$ is the mean annual air temperature at the GRIP position, and $\alpha=-211.4^{\circ} \mathrm{C}, \beta=-11.88^{\circ} \mathrm{C} \times \%^{-1}, \gamma$ $=-0.1925^{\circ} \mathrm{C} \times \%^{-2}$. From Equation (5),

$$
\Delta T_{\mathrm{air}}(t)=f_{\mathrm{GRIP}} \times\left(T_{\mathrm{ma}}^{\mathrm{GRIP}}(t)-T_{\mathrm{ma}}^{\mathrm{GRIP}}(0)\right) ;
$$

the factor $f_{\text {GRIP }}=0.875$ is chosen such that the simulated ice volume at the Last Glacial Maximum (LGM) fits the sea-level $\left(z_{\mathrm{sl}}\right)$ low derived from the SPECMAP $\delta^{18} \mathrm{O}$ 
record via $z_{\mathrm{sl}}[\mathrm{m}]=-34.83\left(\delta^{18} \mathrm{O}[\%]+1.93\right)($ Imbrie and others, 1984).

Lapse rate: $\gamma_{\mathrm{t}}=-6.5^{\circ} \mathrm{C} \mathrm{km}^{-1}$.

Precipitation-temperature coupling: $\gamma_{\mathrm{s}}=0.0429^{\circ} \mathrm{C}^{-1}$, corresponding to a $75 \%$ reduction of $P$ for the mean LGM temperature $\Delta T_{\text {air }}=-17.5^{\circ} \mathrm{C}$ resulting from Equation (6).

Sea level $z_{\text {sll }}$ : computed under the assumption that global sea level is mainly determined by changes of Northern Hemisphere glaciation. This is justified due to the relative stability of the Antarctic ice sheet through glacialinterglacial cycles (Huybrechts, 1992; Budd and others, 1998). With the sea-level equivalent of the simulated Northern Hemisphere glaciation, $H_{\text {sle }}$, and its present value, $H_{\text {sle }}^{\text {present }}=7 \mathrm{~m}$ (Greenland plus small ice caps and glaciers),

$$
z_{\mathrm{sl}}(t)=H_{\mathrm{sle}}^{\text {present }}-H_{\mathrm{sle}}(t),
$$

where $z_{\mathrm{sl}}=0$ corresponds to the present sea level and positive (negative) values denote higher (lower) stands.

\section{Simulation nt016:}

Air-temperature forcing: Vostok air-temperature history $T_{\mathrm{ma}}^{\mathrm{Vostok}}(t)$ derived from the $\delta \mathrm{D}$ profile of the east Antarctic Vostok core (Jouzel and others, 1993, 1996), then

$$
\Delta T_{\text {air }}(t)=f_{\text {Vostok }} \times\left(T_{\text {ma }}^{\text {Vostok }}(t)-T_{\text {ma }}^{\text {Vostok }}(0)\right) .
$$

Again, the factor $f_{\text {Vostok }}$ serves to provide agreement between simulated LGM ice volume and SPECMAP sea-level low. Because the Vostok signal is much weaker than the GRIP signal and apparently underestimates the Northern Hemispheric temperature variations, the value $f_{\text {Vostok }}=2$ is applied here.

Further settings, see simulation nt012.

\section{RESULTS AND DISCUSSION}

Figure 2 depicts the sea-level history resulting from simulations nt012 and nt016 versus the SPECMAP record. When

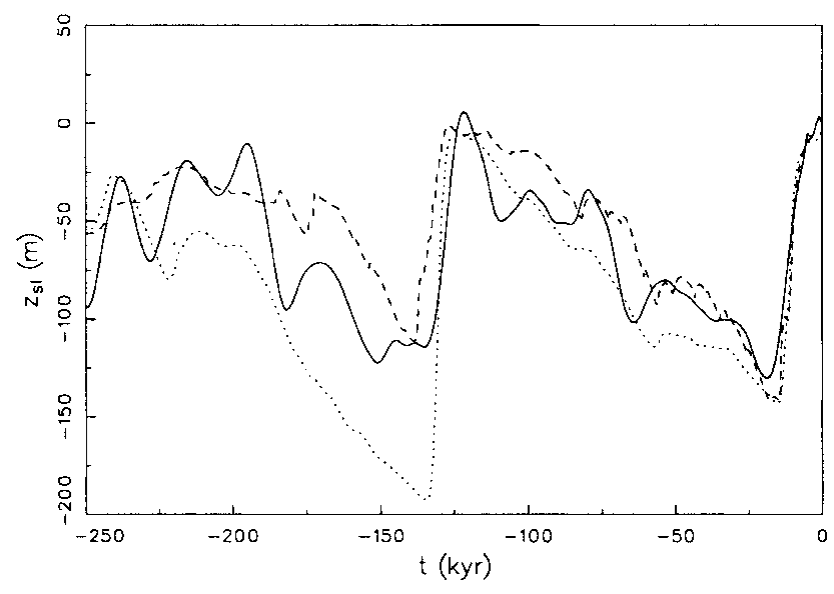

Fig. 2. Global sea level $z_{\mathrm{sl}}$ resulting from computed (simulations nt012, dashed, and nt016, dotted) changes of Northern Hemisphere glaciation vs the SPECMAP record converted to sea level via $z_{\mathrm{sl}}[\mathrm{m}]=-34.83\left(\delta^{18} \mathrm{O}[\% \mathrm{\%}]+1.93\right)$ (Imbrie and others, 1984; solid).
Table 1. Rates of sea-level rise (interval $z_{\mathrm{sl}}=-110 \mathrm{~m} \ldots$ $-10 \mathrm{~m}$ ) for the deglaciation events of Termination II and Termination I, respectively. Simulations nt012, nt016 vs SPECMAP record

\begin{tabular}{lccc}
\hline Deglaciation event & $\begin{array}{c}\text { nt012 } \\
\mathrm{m} \mathrm{kyr}^{-1}\end{array}$ & $\begin{array}{c}\text { nt016 } \\
\mathrm{myr}^{-1}\end{array}$ & $\begin{array}{c}\text { SPECMAP kyr } \\
\end{array}$ \\
\hline Termination II & 11.3 & 25.6 & 11.0 \\
Termination I & 11.8 & 13.4 & 10.8 \\
\hline
\end{tabular}

Table 2. Time at which the sea level reaches the close-tointerglacial value $z_{\mathrm{sl}}=-10 \mathrm{~m}$ during Termination II and Termination I, respectively. Simulations nt012, nt016 vs SPECMAP record

\begin{tabular}{lrrc}
\hline Deglaciation event & $n t 012$ & $n t 016$ & SPECMAP \\
& kyr BP & kyr BP & kyr BP \\
\hline Termination II & 129.1 & 126.8 & 124.7 \\
Termination I & 5.2 & 4.8 & 5.4 \\
\hline
\end{tabular}

comparing the GRIP-driven simulation nt012 with SPECMAP, we see first a good agreement for the main glacial lows and interglacial highs, which confirms the realistic choice of the factor $f_{\text {GRIP }}$ in Equation (6). The rates of sea-level rise during Termination II (stages 6/5) and Termination I (stages 2/1) are in good agreement as well (Table 1). However, the simulated deglaciation of Termination II occurs approximately 5000 years earlier than the one of the SPECMAP data, whereas there is an almost perfect coincidence for Termination I. This is further demonstrated by the times at which the respective sea level reaches the close-to-interglacial

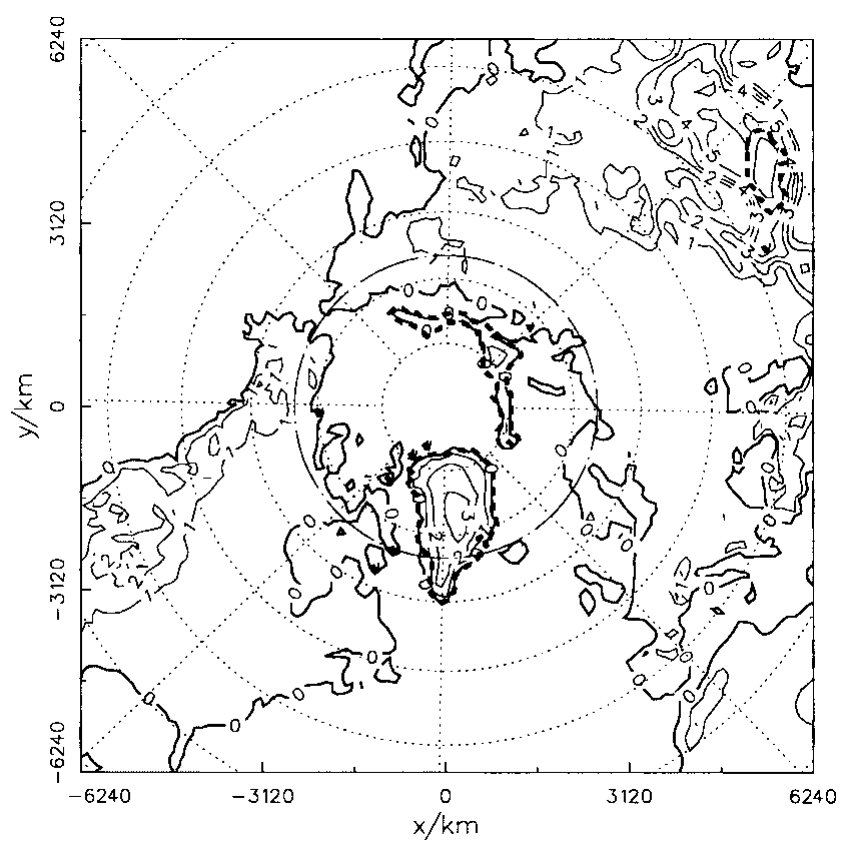

Fig. 3. Simulation nt012: present surface topography, in $\mathrm{km}$ above mean present sea level. Contour spacing is $1 \mathrm{~km}$, latitude circles are spaced by $10^{\circ}$. Dashed heavy lines indicate the ice margins. 

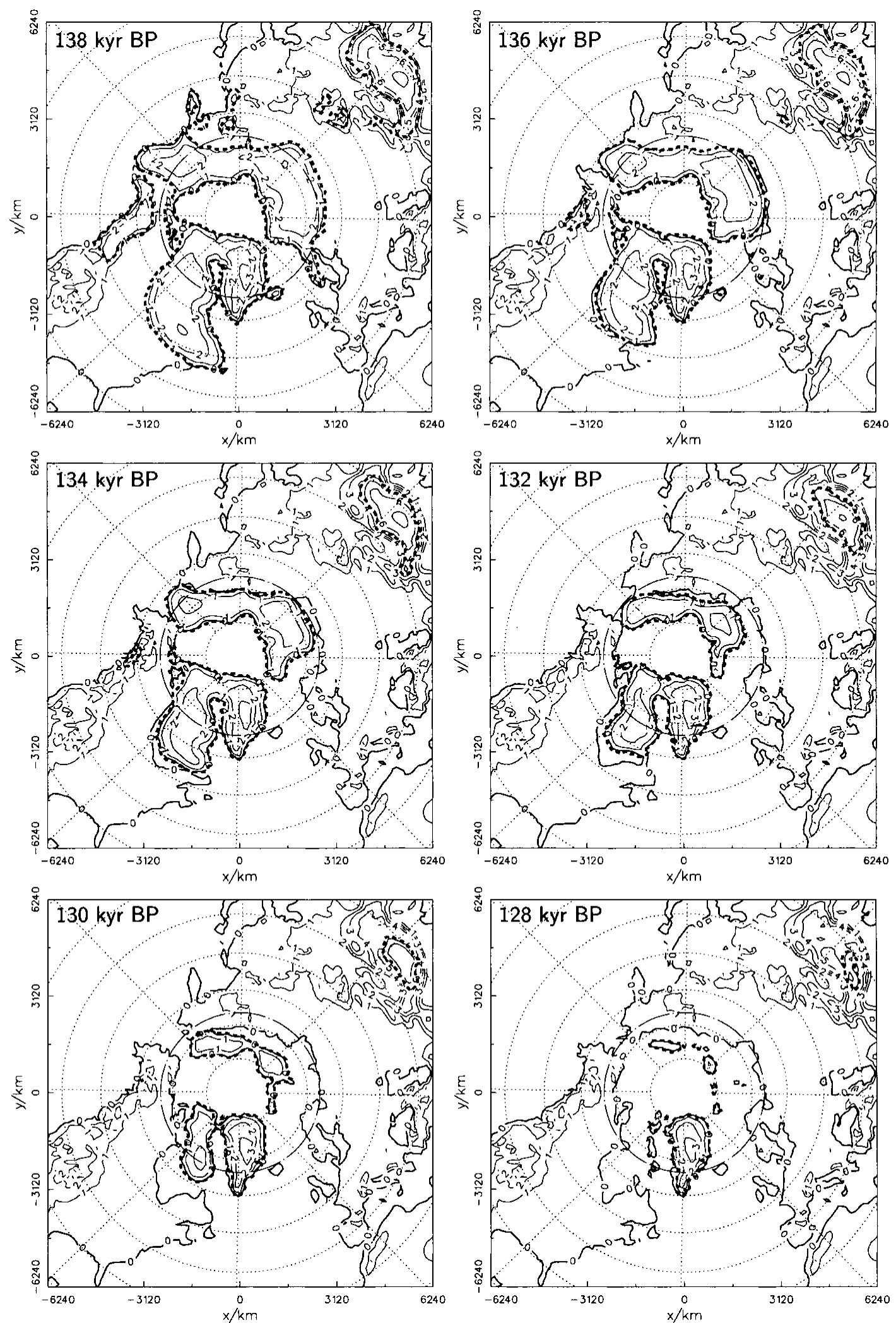

Fig. 4. Simulation nt012: surface topography for the deglaciation during Termination II ( $t=138,136,134,132,130,128 \mathrm{kyr}$ BP), in $\mathrm{km}$ above mean present sea level. Contour spacing is $1 \mathrm{~km}$, latitude circles are spaced by $10^{\circ}$. Dashed heavy lines indicate the ice margins.

value $z_{\mathrm{sl}}=-10 \mathrm{~m}$ (Table 2): for Termination II, the times of nt012 and SPECMAP differ by 4400 years, for Termination I only by 200 years. This finding supports the result of our coral-reef data, even though the difference for Termination II is somewhat smaller than the $\sim 6000$ years according to the data (see section 2).

It is further conspicuous that the simulated and SPECMAP stadials and interstadials fall together rather well for the Wisconsinan ice age, whereas there are large discrepancies for the Saale glacial. This may be so because of flow irregularities in the near-bottom ice of central Greenland which affect the stratigraphy of the $\delta^{18} \mathrm{O}$ record of the GRIP core and/or the breakdown of the $\delta^{18} \mathrm{O}$ temperature relation (Equation (5)) so far in the past (Johnsen, 1995; Thorsteinsson, 1996).

The present glaciation of the Northern Hemisphere, which consists mainly of the Greenland ice sheet, is repro- 

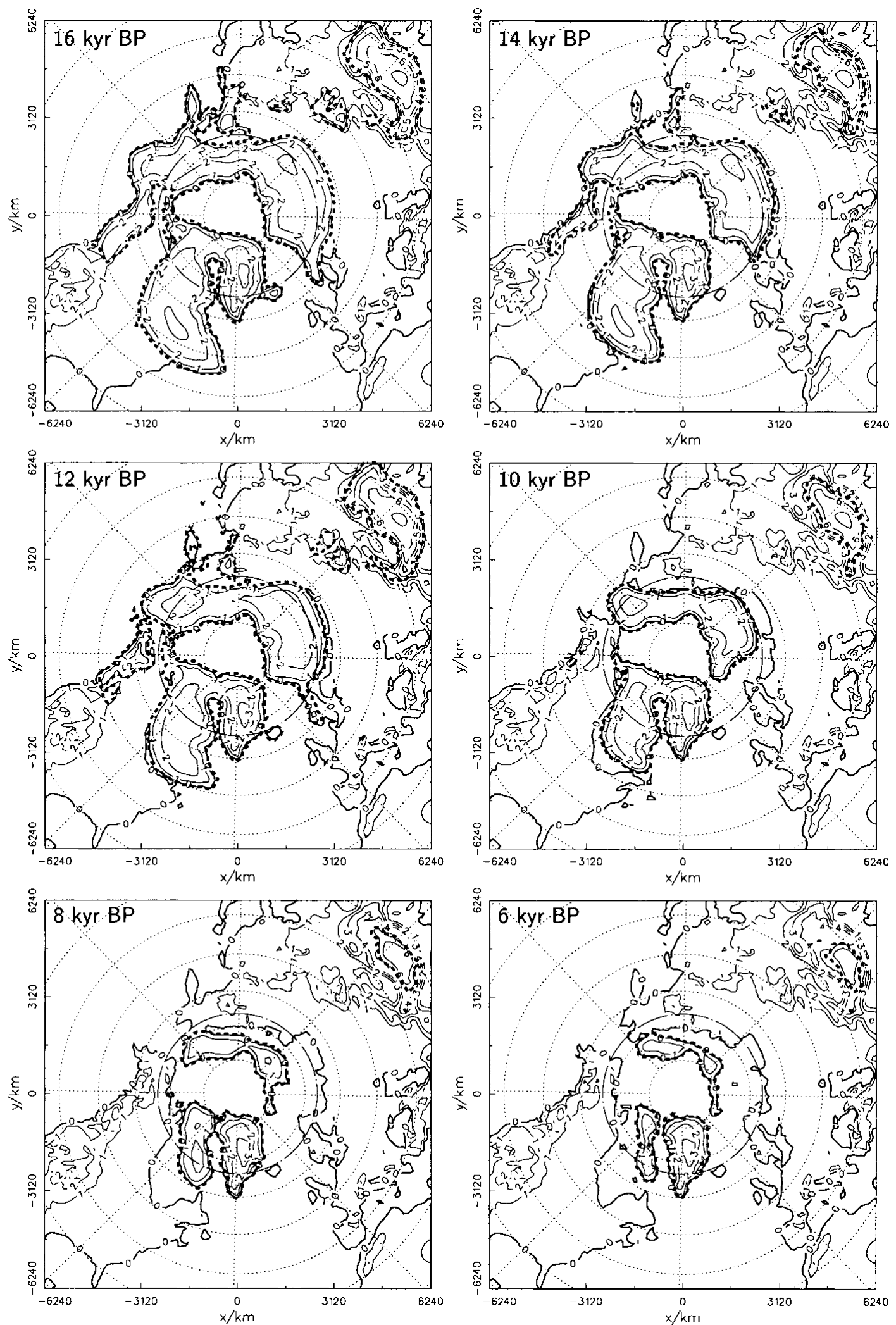

Fig. 5. Same as Figure 4, but for deglaciation during Termination I ( $t=16,14,12,10,8,6$ kyr BP).

duced well by simulation nt012. The simulated present sea level is $5.1 \mathrm{~m}$ lower than the actual one due to some ice remnants in Tibet and the Russian Arctic which do not exist in reality (Fig. 3).

The correspondence between the Vostok-driven simulation nt016 and SPECMAP is generally worse than the one between nt012 and SPECMAP, which is no surprise because an Antarctic record is used to force a simulation of the Northern Hemisphere. The choice of the factor $f_{\text {Vostok }}$ in
Equation (8) assures good agreement for the LGM sea-level low; this holds also for the Eemian and Holocene highs. However, the simulated sea levels in the course of the Wisconsinan and, even more pronounced in the course of the Saale glacial, are distinctly lower than the SPECMAP sea levels (Fig. 2). Correspondingly, the rate of sea-level rise during Termination II is more than twice the SPECMAP value, whereas it is only moderately larger for Termination I (Table 1). 
As for the dating of Terminations I and II, we find essentially the same behaviour as between nt012 and SPECMAP. The close-to-interglacial sea level $z_{\mathrm{sl}}=-10 \mathrm{~m}$ of $\mathrm{nt} 016$ is reached 2100 years earlier than the one of the SPECMAP data for Termination II, whereas the difference is much smaller (600 years) for Termination I (Table 2). Evidently, an early sea-level high during substage $5 \mathrm{e}$ is also predicted by simulation nt016, even though the finding is less significant than for simulation nt012.

Again, due to some artificial ice remnants in Tibet and the Russian Arctic, the simulated present sea level does not entirely reach the real one. The discrepancy amounts to $8.2 \mathrm{~m}$, somewhat more than for simulation nt012.

Figures 4 and 5 show the surface topography for the GRIP-driven simulation nt012 for the deglaciations during Terminations II and I, respectively, in 2 kyr intervals. Evidently, both deglaciation events proceed very similarly. The initial state consists of a strongly glaciated Northern Hemisphere with a Laurentide ice sheet reaching down to approximately $45^{\circ} \mathrm{N}$ and connected to the Greenland ice sheet, a Fennoscandian ice sheet connected to a large Siberian ice sheet, a Tibetan ice sheet between $30^{\circ} \mathrm{N}$ and $40^{\circ} \mathrm{N}$, a glaciated Bering Strait and a Cordilleran ice sheet down to $50^{\circ} \mathrm{N}$, with generally slightly more ice at the onset of Termination I. Comparison of the simulated glaciation at 16 kyr BP with current reconstructions of the LGM (Denton and Hughes, 1981; Peltier, 1994) shows that the ice covers of east Siberia and the Bering Strait are probably unrealistic, whereas the Laurentide ice sheet is somewhat too small. This is a common problem of ice-sheet models (e.g. Huybrechts and T'siobbel, 1995; Budd and others, 1998) which may be due to topography-induced changes of the atmospheric circulation not accounted for by simple climate parameterizations like Equations (2)-(4). For both deglaciation events, 6000 years after the onset, the Fennoscandian and Cordilleran ice sheets have disappeared completely, whereas the Laurentide, Siberian and Tibetan ice sheets are more stable, and Greenland remains essentially unchanged apart from a slight reduction in area. After 10000 years of deglaciation, only the Greenland ice sheet and the already mentioned ice remnants in the Russian Arctic and Tibet remain, the latter being less pronounced in the very warm Eemian than in the slightly colder Holocene. This timescale for deglaciation following a glacial-interglacial climate switch was already obtained by the simulations of Huybrechts and T'siobbel (1995).

As stated above, the simulation results support an early Eemian sea-level high. If this is indeed true, the traditional idea of a direct cause-and-effect relationship between Milankovitch forcing at $65^{\circ} \mathrm{N}$ and global sea-level response must be abandoned. This conclusion has been anticipated by the results of a recent two-dimensional global energybalance model simulation (Crowley, 1994; Crowley and $\mathrm{Kim}, 1994)$, for which the $65^{\circ} \mathrm{N}$ insolation forcing was replaced by a latitude-dependent approach. The model results suggest that, given global insolation values at that time, an early deglaciation during Termination II can be expected. Model output shows that zonally averaged July temperatures over critical Northern Hemisphere latitudes with ice cover $\left(50-70^{\circ} \mathrm{N}\right)$ were about $2.5^{\circ} \mathrm{C}$ warmer than at present by about $130 \mathrm{kyr} \mathrm{BP}$, and warming in the highest latitudes exceeds the present by $1-1.5^{\circ} \mathrm{C}$ as early as $134 \mathrm{kyr}$ BP. It can therefore be argued that an early sea-level high during substage $5 \mathrm{e}$ is entirely consistent with Milankovitch forcing, provided the meridional variation of the insolation is accounted for.

\section{CONCLUSION}

The results of the simulations of Northern Hemisphere glaciation, in particular the GRIP-driven one, provide good agreement for the rates and total amounts of the deglaciations during Terminations I and II when compared to the SPECMAP record. Further, they support the evidence from the Houtman Abrolhos coral-reef data of different deglaciation histories in relation to Milankovitch forcing at $65^{\circ} \mathrm{N}$ during these events. While the timing details between the simulation results and the sea-level history inferred from the data differ, the insolation lead-lag relationships are the same, which makes it more difficult to reject the high-resolutionTIMS U-series dates as diagenetic artefacts.

If our views are correct, some adjustment may have to be made to the SPECMAP chronology, which is tuned to insolation at this latitude. More important, however, is the insight that there is no straightforward causality relation between $65^{\circ} \mathrm{N}$ insolation and Northern Hemisphere deglaciation. Of course, this immediately raises the question: what is the reason for global sea-level changes, if not Milankovitch forcing? A promising way out of this dilemma is to replace the single-forcing latitude by a latitude-dependent insolation forcing in order to meet the complexity of the climate system more adequately.

\section{ACKNOWLEDGEMENTS}

The adaption of the SICOPOLIS ice-sheet model to the entire Northern Hemisphere was performed during a visit of $\mathrm{R}$. Greve to the Antarctic CRC, Hobart, Tasmania. I wish to thank K. Hutter for helping arrange this visit, the ice-sheetmodelling group of the Antarctic CRC, in particular W. F. Budd, B. Coutts, T. H. Jacka and R. Warner for their help and hospitality during this time, and the Adolf-MesserStiftung for generous financial support. The comments of M. Prentice and an anonymous reviewer on an earlier version of the manuscript have helped to improve the writing and clarity of this paper considerably.

\section{REFERENGES}

Bloom, A. L., W. S. Broecker, J. M. A. Chappell, R. K. Matthews and K. J. Mesolella. 1974. Quaternary sea level fluctuations on a tectonic coast: new ${ }^{230} \mathrm{Th} /{ }^{234} \mathrm{U}$ dates from the Huon Peninsula, New Guinea. Quat. Res., 4(2), 185-205.

Braithwaite, R. J. and O. B. Olesen. 1989. Calculation of glacier ablation from air temperature, West Greenland. In Oerlemans, J., ed. Glacier fluctuations and climatic change. Dordrecht, etc., Kluwer Academic Publishers, 219-233.

Budd, W. F. and I. N. Smith. 1981. The growth and retreat of ice sheets in response to orbital radiation changes. International Association of Hydrological Sciences Publication 131 (Symposium at Canberra 1979-Sea Level, Ice and Climatic Change), 369-409.

Budd, W. F., B. Coutts and R. C. Warner. 1998. Modelling the Antarctic and Northern Hemisphere ice-sheet changes with global climate through the glacial cycle. Ann. Glaciol., 27, 153-160.

Calov, R. and K. Hutter. 1997. Large scale motion and temperature distributions in land based ice shields - the Greenland ice sheet in response to various climatic scenarios. Arch. Mech., 49(5), 919-962.

Chen, J. H., H. A. Curran, B. White and G. J. Wasserburg. 1991. Precise chronology of the last interglacial period: ${ }^{234} \mathrm{U}^{2}{ }^{230} \mathrm{Th}$ data from fossil coral reefs in the Bahamas. Geol. Soc. Am. Bull., 103, 82-97.

Crowley, T. J. 1994. Potential reconciliation of Devil's Hole and deep-sea Pleistocene chronologies. Paleoceanography, 91, 1-5.

Crowley, T. J. and K.Y. Kim. 1994. Milankovitch forcing of the Last Inter- 
glacial sea level. Science, 265(5178), 1566-1568.

Dansgaard, W. and 10 others. 1993. Evidence for general instability of past climate from a 250-kyr ice-core record. Nature, 364(6434), 218-220..

Denton, G. H. and T. J. Hughes, eds. 1981. The last great ice sheets. New York, etc., John Wiley and Sons.

Edwards, R. L., J. H. Chen and G. J. Wasserburg. 1987a. Precise timing of the last interglacial from mass spectrometric determinations of thorium-230 in corals. Science, 236, 1547-1553.

Edwards, R. L., J. H. Chen and G. J. Wasserburg. 1987b. ${ }^{238} \mathrm{U}_{-}{ }^{234} \mathrm{U}-{ }^{230} \mathrm{Th}^{232} \mathrm{Th}$ systematics and the precise measurement of time over the past 500000 years. Earth Planet. Sci. Lett., 81, 175-192.

Edwards, R. L., J. H. Chen, M. T. Murrell and S. J. Goldstein. 1997. Protactinium-231 dating of carbonates by thermal ionization mass spectrometry: implications for Quaternary climate change. Science, 276, 782-786.

Eisenhauer, A. and 6 others. 1993. Holocene sea-level determinations relative to the Australian continent: U/Th (TIMS) and ${ }^{14} \mathrm{C}$ (AMS) dating of coral cores from the Abrolhos. Earth Planet. Sci. Lett., 114, 529-547.

Eisenhauer, A., Z. R. Zhu, L. B. Collins, K.-H. Wyrwoll and R. Eichstaetter. 1996. The last interglacial sea level change: new evidence from the Abrolhos Islands, West Australia. Geol. Rundsch., 85, 606-614.

ETOPO5. 1988. Data announcement 88-MGC-02, digital relief of the surface of the Earth. Boulder, CO, U.S. Department of Commerce. NOAA. National Geophysical Data Center.

Fowler, A. C. and D. A. Larson. 1978. On the flow of polythermal glaciers. I: Model and preliminary analysis. Proc. R. Soc. London, Ser. A, 363(1713), 217-242.

Gallup, D. C., R. L. Edwards and R. G. Johnson. 1994. The timing of high sea levels over the last 200000 years. Science, 263(5148), 796-800.

Greve, R. 1995. Thermomechanisches Verhalten polythermer EisschildeTheorie, Analytik, Numerik. (Ph.D. thesis, Technische Hochschule, Darmstadt.)

Greve, R. 1997a. Application of a polythermal three-dimensional ice sheet model to the Greenland ice sheet: response to steady-state and transient climate scenarios. 7. Climate, 10 (5), 901-918.

Greve, R. 1997b. A continuum-mechanical formulation for shallow polythermal ice sheets. Philos. Trans. R. Soc. London, Ser. A, 355, 921-974.

Hamelin, B., E. Bard, A. Zindler and R. G. Fairbanks. 1991. ${ }^{234} \mathrm{U} /{ }^{238} \mathrm{U}$ mass spectrometry of corals; how accurate is the U-Th age of the last interglacial period? Earth Planet. Sci. Lett., 106, 169-180.

Henderson, G. M., A. S. Cohen and R. K. O'Nions. 1993. ${ }^{234} \mathrm{U} /{ }^{238} \mathrm{U}$ mass ratios and ${ }^{230} \mathrm{Th}$ ages for the Haterum Atoll corals: implications for coral diagenesis and seawater ${ }^{234} \mathrm{U} /{ }^{238} \mathrm{U}$ ratios. Earth Planet. Sci. Lett., $115,65-73$.

Hutter, K. 1982. A mathematical model of polythermal glaciers and ice sheets. Geophys. Astrophys. Fluid Dyn., 21 (3-4), 201-224.

Hutter, K. 1993. Thermo-mechanically coupled ice-sheet response-cold, polythermal, temperate. f. Glaciol., 39(131), 65-86.

Huybrechts, P. 1992. The Antarctic ice sheet and environmental change: a three-dimensional modelling study. Ber. Polarforsch. 99.

Huybrechts, P. 1993. Glaciological modelling of the Late Cenozoic East Antarctic ice sheet: stability or dynamism? Geogr. Ann., 75A(4), 221-238.
Huybrechts, P. and S. T'siobbel. 1995. Thermomechanical modelling of Northern Hemisphere ice sheets with a two-level mass-balance parameterization. Ann. Glaciol., 21, 111-116.

Imbrie, J. and 8 others. 1984. The orbital theory of Pleistocene climate: support from a revised chronology of the marine ${ }^{18} \mathrm{O}$ record. In Berger, A., J. Imbrie, J. Hays, G. Kukla and B. Saltzman, eds. Milankovitch and climate: understanding the response to astronomical forcing. Part 1. Dordrecht, etc., D. Reidel Publishing Co., 269-305. (NATO ASI Series C: Mathematical and Physical Sciences 126.)

Jaeger, L. 1976. Monatskarten des Niederschlags für die ganze Erde. Ber. Dtsch. Wetterdienstes, 18 (139).

Johnsen, S. J., D. Dahl-Jensen, W. Dansgaard and N. S. Gundestrup. 1995. Greenland paleotemperatures derived from GRIP borehole temperature and ice core isotope profiles. Tellus, 47B(5), 624-629.

Jouzel, J. and 16 others. 1993. Extending the Vostok ice-core record of palaeoclimate to the penultimate glacial period. Nature, 364(6436), 407-411.

Jouzel, J. and 14 others. 1996. Climatic interpretation of the recently extended Vostok ice core records. Climate Dyn., 12(8), 513-521.

Kaufman, A. 1986. The distribution of ${ }^{230} \mathrm{Th} /{ }^{234} \mathrm{U}$ ages in corals and the number of last interglacial high sea stands. Quat. Res., 25(1), 55-62.

Le Meur, E. and P. Huybrechts. 1996. A comparison of different ways of dealing with isostasy: examples from modelling the Antarctic ice sheet during the last glacial cycle. Ann. Glaciol., 23, 309-317.

Letréguilly, A., P. Huybrechts and N. Reeh. 1991. Steady-state characteristics of the Greenland ice sheet under different climates. F. Glaciol., 37(125), 149-157.

Marsiat, I. 1994. Simulation of the Northern Hemisphere continental ice sheets over the last glacial-interglacial cycle: experiments with a latitude-longitude vertically integrated ice sheet model coupled to a zonally averaged climate model. Paleoclimates, 1, 59-98.

Peltier, W. R. 1994. Ice age paleotopography. Science, 265(5169), 195-201.

Reeh, N. 1991. Parameterization of melt rate and surface temperature on the Greenland ice sheet. Polarforschung, 59(3), 1989, 113-128.

Stirling, C. H., T. M. Esat, M. T. McCulloch and K. Lambeck. 1995. Highprecision U-series dating of corals from Western Australia and implications for the timing and duration of the Last Interglacial. Earth Planet. Sci. Lett., 135, 115-130.

Szabo, B., K. R. Ludwig, D. R. Muhs and K. R. Simmons. 1994. Thorium230 ages of corals and duration of the last interglacial sea-level high stand on Oahu. Science, 266, 93-96.

Thorsteinsson, T. 1996. Textures and fabrics in the GRIP ice core, in relation to climate history and ice deformation. Ber. Polarforsch. 205.

Winograd, I. J. and 7 others. 1992. Continuous 500000 year climate record from vein calcite in Devil's Hole, Nevada. Science, 258(5080), 255-260.

Wyrwoll, K.-H., Z. R. Zhu, G. Kendrick, L. Collins and A. Eisenhauer. 1995. Holocene sea-level eveents in Western Australia: revisiting old questions. 7. Coast. Res., Special Issue 17, 321-326.

Zhu, Z. R., K.-H. Wyrwoll, L. B. Collins, J. H. Chen, G. J. Wasserburg and A. Eisenhauer. 1993. High-precision U-series dating of last interglacial events by mass spectrometry: Houtman Abrolhos, Western Australia. Earth Planet. Sci. Lett., 118, 281-293. 